\title{
The Palace of Westminster Courtyards Project: Sourcing Stone for Repair and Conservation
}

\author{
Elizabeth Anne Laycock ${ }^{1}$, David Jefferson ${ }^{2}$ and Steven Hetherington ${ }^{1}$ \\ ${ }^{1}$ Department of the Natural and Built Environment, Sheffield Hallam University, City Campus, \\ Sheffield, S11WB UK, e.a.laycock@shu.ac.uk \\ 2 Jefferson Consulting Limited, The Old Armoury, Crown Business Park, Old Dalby, Melton \\ Mowbray, Leicestershire, LE14 3NQ, UK. enquiries@jeffersonconsulting.co.uk
}

\begin{abstract}
The Palace of Westminster, commonly known as the Houses of Parliament, serves as the meeting place of the House of Commons and the House of Lords and is situated on the north bank of the River Thames in London, England. The site is part of the UNESCO Westminster World Heritage Site. The building was constructed of magnesian limestone, selected following a nationwide survey of building stones carried out by a Government Select Committee. However, some of this stone began to decay soon after construction in the mid 1800s. As the majority of the stonework has survived very well the aim of the work was to source a demonstrably durable material with characteristics which align with the majority of the existing stonework. Samples were taken from the building for petrographic analysis in order to identify compatible material in quarries, either working or which could be re-opened. Durability of the magnesian limestone was assessed using both accepted tests and novel methodology. Large scale walls were constructed in the laboratory and exposed to accelerated frost weathering with realistic temperature parameters. The logistical problems with sourcing the original building material, the nature of the transport and the masons' unfamiliarity with the stone may all have played a part in undermining its durability. When magnesian limestone is properly selected and used correctly, its reputation for being of poor durability is largely unfounded. Suitable sources for replacement stone were located which provided several options for both immediate and long-term sourcing for repair and conservation.
\end{abstract}

Keywords: Magnesian Limestone, Durability, Restoration, Weathering, Freeze Thaw.

\section{Introduction}

As with all historic buildings, natural wear and tear results in the necessity of repairing the fabric of the Palace of Westminster from time to time. Wherever possible this is undertaken with either the original stone where this is still available, or a stone which is petrographically, chemically and visually similar to the original, when the original source is unknown or has been worked out or sterilised by development. Unfortunately, over the years a number of stories regarding the unsuitability of the stone used by Barry to build the 'New' Houses of Parliament after the disastrous fire of 1834, have become to be regarded as fact (Shenton, n.d.).

\section{The Historic Construction}

The original stone for the Palace of Westminster selected by the Commissioners appointed by Parliament, was magnesian limestone from Bolsover Moor. The rate of extraction of acceptable stone with suitable bed heights could not be maintained and production was switched to Mansfield Woodhouse. The required bed heights again proved impossible to achieve. In 1834, only three years after the foundation stone had been laid, and with the walls of the new building about four to five metres in height, all the external stone was being supplied from the Anston 
area. The Anston quarries finally fulfilled one of the main criteria for the supply of stone, being both of acceptable bed height and able to meet a supply rate which matched the planned speed of construction.

Stone was transported from the site using horse-drawn wagons to the Chesterfield canal and loaded into boats at Dog Kennel's Wharfe after storage at Kiveton Park. (Richardson, 1999). From there it was carried to West Stockwith to be transferred on to Trent sloops for the rest of the two-week journey to the Humber and then down the North Sea coast to the Thames and Westminster. Lott and Richardson (1997) highlight the 'formidable' scale of the operation as 400 imperial tons were carried by barge each month (approximately 4880 metric tons per annum). Anston Stone was used in the whole building except 'the upper part of the towers and the front towards Abingdon Street' (Elsden and Howe, 1923).

Soon after the building was completed signs of degradation started to appear on some of the stonework. These problems were almost certainly a result of the demand for large quantities of stone in relatively short time, compounded by the complexities of the formation of the of magnesian limestone (Smith, 1995). While acceptable building stone is available, in a range of bed heights, its quality can be variable and requires careful selection of appropriate material. There were pressures to complete the building quickly and at minimum cost. Many of the masons involved in constructing the building would have been unfamiliar with magnesian limestone. A government select committee in 1861 reported that there were 17 beds in various thicknesses from $1 \mathrm{ft}$ to a few inches but that both the good quality Anston and the poorer were 'worked indiscriminately" with no supervision within the quarries and as a result "So little stone was rejected at the quarries that almost the only waste was that derived from the cutting of the

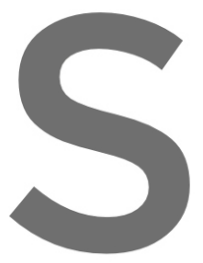
blocks" following which
throughout the Winter"
processing (Elsden and
orientation and thus mu
slackness" (Elsden and $\mathrm{H}$
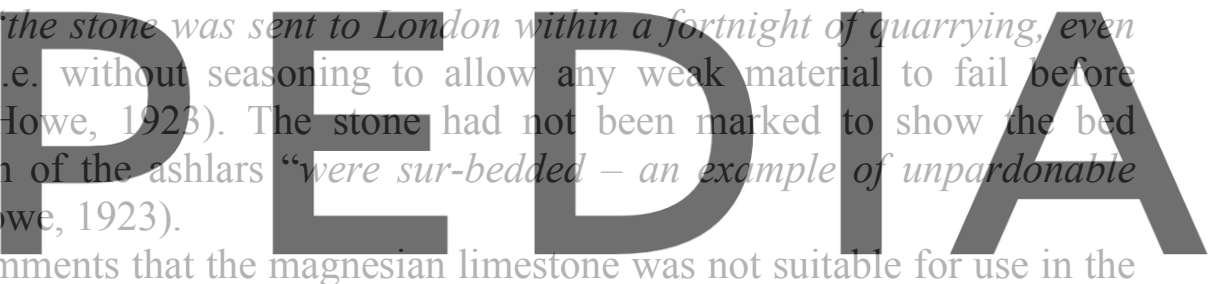

polluted atmosphere of London, the majority of the stonework has survived extremely well.

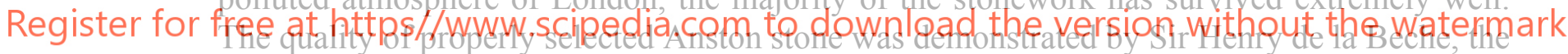

first Director of the Geological Survey, who was involved in selecting the stone for the Palace of Westminster, when he used it for the new Museum of Practical Geology on Jermyn Street. Magnesian limestones have been used successfully in polluted atmospheres outside London; in Mansfield and Doncaster for example. Petrographic and electron microscope studies have shown that one reason for this durability may be the thin layer of crystalline gypsum which can develop on the surface of the stone, protecting it from further reaction.

\section{The Original Stone}

The magnesian limestones were originally formed in a shallow near-shore environment, ranging from sabkha muds to lagoonal oöidal banks, shell banks, patch reefs and detrital deposits. These strata were petrographically variable even before dolomitisation which overwrites original depositional fabrics. Thin beds of marl are not uncommon, and this clayey material is also present as very thin films within some of the limestone. In terms of petrography, chemistry and physical properties, a considerable range of stones exists as is evidenced by the colour and texture of the stones in historic buildings from Nottingham to the Tyne. The fine-grained nature of some of the stones and dolomitisation often make it impossible to identify the type and source of stone purely from a visual study of the surface alone. There are probably as many different types of magnesian limestone in the area from which the stone was sourced as there are different 
types of ordinary limestone in the UK.

In order to determine the types of stone which may be required for the conservation work in the Courtyards, and elsewhere on the exterior of the Palace, it is first necessary to study and sample all the stonework within the seven courtyards, aiming to identify the existence of significant variations and, if they do exist, the number of stone types present and their distribution. Although all the fabric is relatively contemporaneous, the problems encountered with the supply of stone to the 'New' Houses of Parliament between 1839 and about 1852, and possible modifications since that time, may well have resulted in individual elevations utilising different building stones (Bolsover Moor, Mansfield Woodhouse, North Anston), and all three magnesian limestones may conceivably be present in at least some of the elevations.

Careful sampling of the fabric was therefore undertaken and 15 samples of magnesian limestone were taken from locations in the Chancellor's Court, The State Officers Court, The Peer's Court and The Star Chamber Court. A further piece of stone was provided, having become detached at some point in the past. The original context of this stone was unknown and was found to be Caen and not magnesian limestone (Yates, 2014; Palmer 2014) and is not discussed further. The lack of supervision and selection throughout the process in an attempt to finish the original work as speedily as possible and at minimum cost can be witnessed upon survey of the fabric of the building. It appears likely that the most damaged stonework involving the Anston stone is where softer material has been used for carved work, where poor stone selection has allowed flawed stone to be inserted in the building and where the stone has been incorrectly laid.
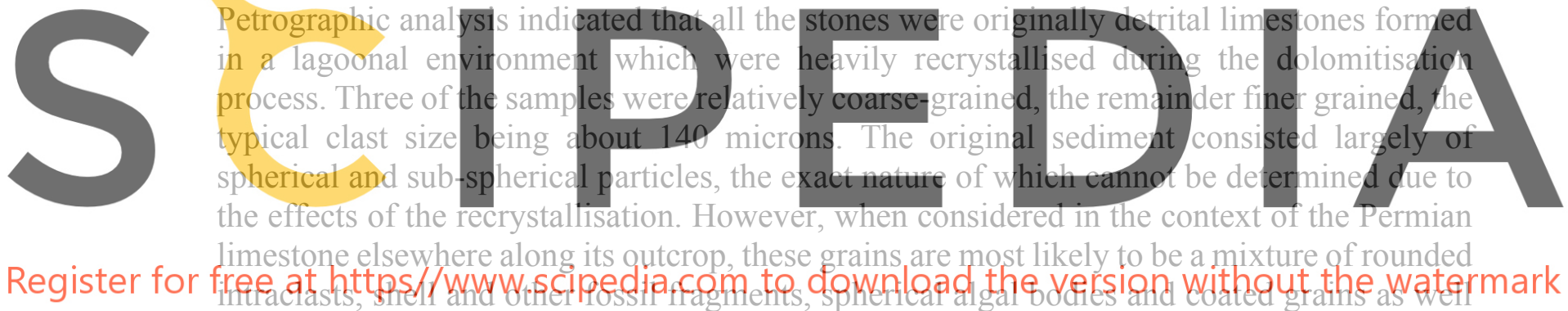

as true oöids. Some of the samples indicate that some of the shell and other fossil fragments could have been quite large. Aithough the finer-grained matrix is iargely amorphous due to the dolomitisation, there are areas which suggest that algal mats may have been present. Overall, the assemblage suggests a typical Permian shallow water reefal and lagoonal environment, typical of the much of the Permian magnesian limestone outcrop.

There was no pattern in the use of the stone according to the study of the petrography and the fabric from which the samples were obtained. This apparent mixing of stone types within the fabric does have an advantage when conservation is undertaken. Due to the variation in the fabric there is no requirement for the exact matching of petrographies when a stone is repaired or replaced. Providing that the replacement material originated in a similar limestone facies to the original stone, and the degree and type of dolomitisation together with its physical characteristics, is similar, the most appropriate new stone for the location within the building can probably be selected.

\section{Locating Replacements}

Given the importance of the building, very careful consideration must be paid to the potential sources which most closely matched the fabric both visually and petrographically, and with acceptable chemical characteristics (e.g. the concentrations of silica, magnesium and iron), 
similar porosity, permeability and compressive strengths, and of the same geological age. Sources that most closely matched these were available from quarries not operating commercially at the time of assessment. The type of dolomite fabric seen in the samples from the Courtyards, and elsewhere on the exterior of the building, is typical of that found in the area between Doncaster and Mansfield. However, the colour of the stone within this area can vary between pure white and pale brown. Obtaining a good colour and texture match restricts the search area for new stone to within about 20 kilometres of Anston.

All the magnesian limestone quarries within the target area were visited in order to determine whether or not stone with the correct texture and colour was potentially available. This included closed and mothballed quarries, as well as ones which were operating. Where it was not possible to obtain permission for access to a quarry, the visual appearance of the stone, and in particular its colour, bed height and jointing, was observed from the perimeter. Closer analysis of the stone in such cases was obtained by studying exposures outside, but close to, the quarry. Although there were a considerable number of quarries in the area in the second half of the 19th century, very few now remain. The result of the field studies indicated that Tarmac's quarry at Harrycroft was potentially a suitable source of stone for the repairs and conservation at the Palace of Westminster. Although not active at the time of the survey, reserves of stone remained in a consented area. The quarry is now fully consented and operational. The geology of the site is complex, with the rock being a mixture of patch reefs separated by bedded lagoonal deposits. Structurally the stone is also variable, being cut by faults and, more importantly, by joint features caused by differential compaction within and round the perimeter of the individual reefs. The reef limestones are not suitable for use as a

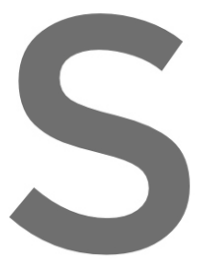
building stone and any res ource must therefor
While the petrography of the material was co
assessment of the durability of the magnesian
collected and tested by Sheffield Hallam Un
request of the architects and following Stage
the commercially operating Cadeby Quarry.
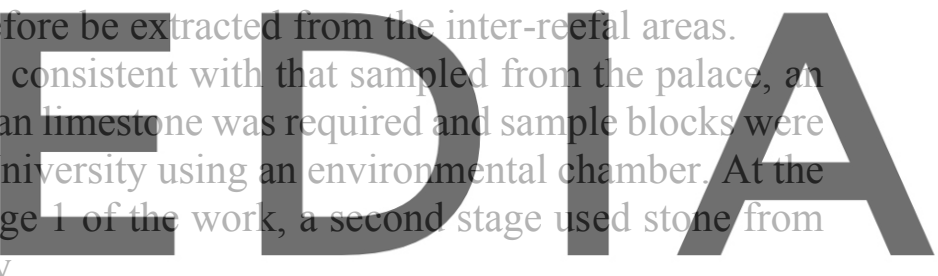

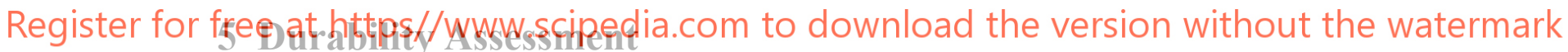

For the first stage of work, four blocks of magnesian limestone were selected. These were chosen in order to represent the variation within the non-biohermal beds at the quarry. The bioherms, or patch reefs, have not been sampled since the stone is irregular and unbedded and contains numerous joints and cracks, probably due to the irregular compaction suffered after burial; it is not suitable for masonry use. The blocks were cut at the masonry yard at the Dean and Chapter quarry at Lincoln Cathedral. All cut blocks were $350 \mathrm{~mm}$ length, $200 \mathrm{~mm}$ depth and $200 \mathrm{~mm}$ height. Block 1 was slightly variable and produced 14 blocks. Block 2 was far more uniform and yielded 8, Block 3 was found to contain a number of vent features in the stone and block 4 was very fractured and contained cavities and both were deemed unacceptable. Block 5 was from a different quarry in the Warmsworth area which was also under consideration at Phase 1 (should there be any problems with obtaining stone from Anston). From each set (1,2 and 5) a total of three blocks were selected as representative for inclusion in the first stage wall. Type-t thermocouples were embedded in one block of each stone type to allow the monitoring of response to freezing and ensure that the conditions required for damage were created, while working within realistic temperatures. A test wall was built using 1:3 St Astier NHL 3.5 and coarse graded sand which has been used in previous work and was found to be of suitable strength to prevent premature sacrificial weathering of mortar (Laycock et al, 2008; Laycock, 2002). Panels were isolated from the 
surrounding chamber using polystyrene sheeting and were sealed to prevent water ingress from above or around the sides of the panels (Figure 1). Chamber conditions were verified by test run with the wall in situ to confirm thermal performance. Testing commenced as soon as chamber conditions were confirmed. A study of data from the Meteorological Office suggested that a moderate frost cycle should be utilised. Chamber temperatures were initially set at -4 but the frost front did not penetrate deeply enough into the stone to initiate damage (Laycock, 1997). It was therefore incrementally lowered when the panel was in situ in order to ensure that the frost front passed through the block to a depth of $30 \mathrm{~mm}$ and released during the thaw cycle. This regime was found in previous work on the Magnesian Limestone to cause damage. This resulted in a final cycle between +8 to $-10^{\circ} \mathrm{C}$, cooling and warming at $0.45^{\circ} \mathrm{C} / \mathrm{min}, 2$ minutes of simulated rain and 10 cycles per day. The chamber was maintained at $-10^{\circ} \mathrm{C}$ for 14 minutes. A total of 300 freeze/thaw cycles were carried out. Phase 2 repeated this regime with 9 blocks of Cadeby stone cut to the same sizes as before.
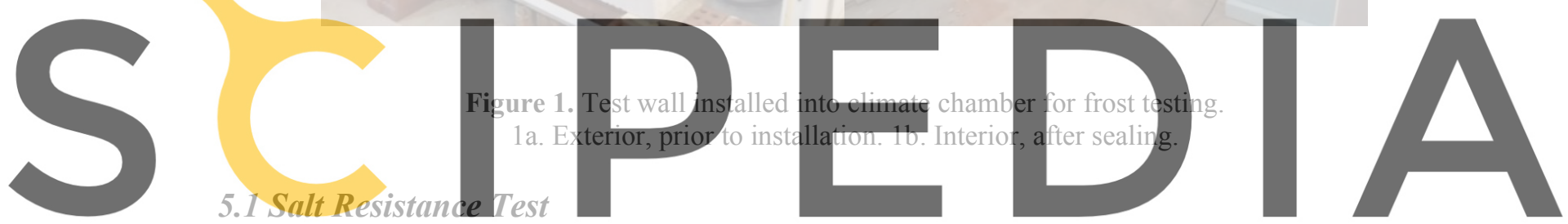

Analogous stones from the fabric of the building were tested with a variety of salt solutions

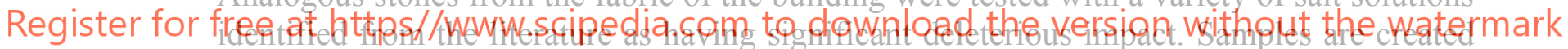
such that the salt solution is forced to evaporate through the faces of the exposed prism, thus simulating conditions required to produce effiorescence and sub-florescence. The experimental method for salt decay by capillary rise and evaporation was used by Scherer (2004) and Lee and Kurtisb (2017). Salt concentrations were based on those used by other authors (Table 1).

Table 1. Salts selected for resistance testing

\begin{tabular}{llcl}
\hline Salt & Relevance to decay & Conc. & $\begin{array}{l}\text { Examples of previous } \\
\text { work }\end{array}$ \\
\hline $\mathrm{NaCl}$ & $\begin{array}{l}\text { commonly used as a de-icing salt, may be } \\
\text { present in older brickwork }\end{array}$ & $5 \%$ & $\begin{array}{l}\text { Goudie (1986) } \\
\text { Lopez-Arce (2008) * }\end{array}$ \\
\hline $\mathrm{NaSO4} 4$ & $\begin{array}{l}\text { Salt used in standard testing as known to } \\
\text { have highly deleterious effect. }\end{array}$ & $14 \%$ & $\begin{array}{l}\text { EN } 12370 \\
\text { Benavente et al (2001) }\end{array}$ \\
\hline $\mathrm{MgSO} 4$ & $\begin{array}{l}\text { Decay product from deterioration of } \\
\text { dolomite }\end{array}$ & $35 \%$ & Cardell et al (2008) \\
\hline *used 5.3 wt.\% NaCl & & & \\
\end{tabular}




\section{Results}

Visual logging using the method reported in Laycock et al. (2008) of over 300 cycles of simulated weathering confirms that the performance of the Cadeby stone and types 2 and 5 were of similar and low order of deterioration both in terms of area and extent (Figure 2a) and severity of damage. Type 1 manifested significantly more severe damage, over a greater areal extent. This is in direct contrast to the performance of Type 1 in the EN 12370 sulphate crystallisation test (Figure 2b) in which types 2 and 5 demonstrated variable and poorer performance. However, when compared to other samples of magnesian limestone building stone tested in the same way indicate that all types tested in both phases of this work demonstrated excellent resistance to deterioration. The material from Cadeby was found to perform consistently well in all tests carried out.
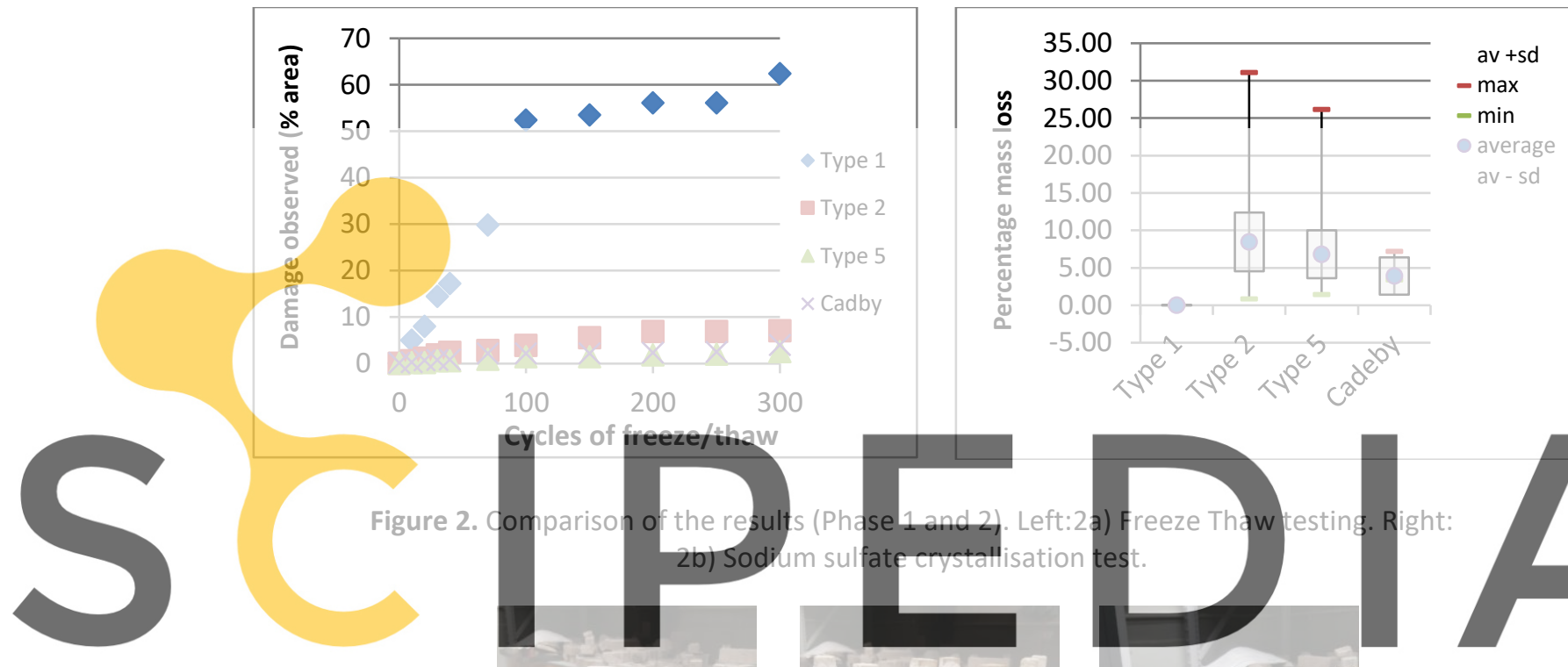

\section{Register for free at https//www.scipedia.com to download the version without the watermark}

a)

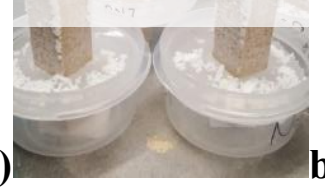

b)

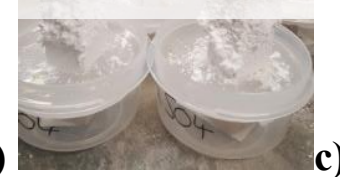

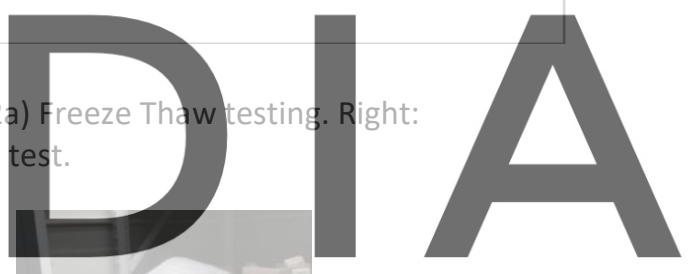

Figure 3. Salt resistance. 2a Anston (type 1) after 120 hours $\mathrm{NaCl}$; 2 b Anston (type 1 ) after 120 hours after 22 days $\mathrm{NaSO}_{4} ; 2$ c Anston (type 1 ) after 30 days $\mathrm{MgSO}_{4}$

Results from the capillary rise and evaporation test included prisms of Clipsham stone, a nonmagnesian stone of good reputation previously used in repair interventions. In this test the Clipsham showed noticable material loss from crystallisation of magnesium sulphate after 24 hours and sodium sulphate after 48 hours. In contrast the Cadeby and Anston stones were affected to a much lower degree by these salts. All stone types tested in the $5 \% \mathrm{NaCl}$ showed low rates of material loss despite rapid evaporation and crystals tended to form as efflorescence rather than sub-fluorescence. Magnesium sulphate solution caused no early damage to the samples, however blistering of the Cadeby was noted in one prism by 120 hours. This test confirms that the Cadeby and Anston stones provided show good resistance to decay by the development of salt crystallisation. 


\section{Conclusion}

The bulk of the original stone for Barry's Palace of Westminster was obtained from quarries at North Anston west of Worksop. Although some of the stone reportedly failed soon after its inclusion in the building, this was almost certainly due to poor quality control during extraction and shipping as well as during construction. This could be attributed demands for a high quantity of stone required in a relatively short period and with a tight budget. This poor project management is evidenced by the mixture of stone petrographies, a result of the distance the stone had to be brought and the likelihood of mixing of stone from different extraction areas at the loading wharf on the Chesterfield canal, again when being off-loaded and reloaded on to sea-going barges, and again when stockpiled at Westminster. This contrasts with accepted good practice to select the appropriate stone for a specific location in the fabric at the quarry. Furthermore, as stone was used and replaced with new stocks shipped in from Anston, the range of various types of petrography would also vary with time. These problems may well have contributed to the reported weathering of some of the stone soon after the building was completed, potentially unsuitable stone being used on occasion for features such as windows or copings.

Where used elsewhere, and with due diligence, magnesian limestone has had a perfectly acceptable durability. There is no reason why the fabric should not be repaired with magnesian limestone with due consideration to the factors outlined in the Technical Advice Note 2016 (Jefferson and Henry, 2016). While some authors have suggested to the contrary (Hunt, 2015), it is completely unacceptable to repair such as building in this with a pure limestone, even one

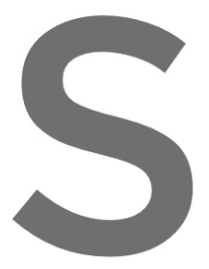
of the highest quality (Jefferson, 2015). Fortunately, the use of the Clipsham into the Palace has the courtyards, in ort of the Lincolnshire magnesian limeston This work assessed
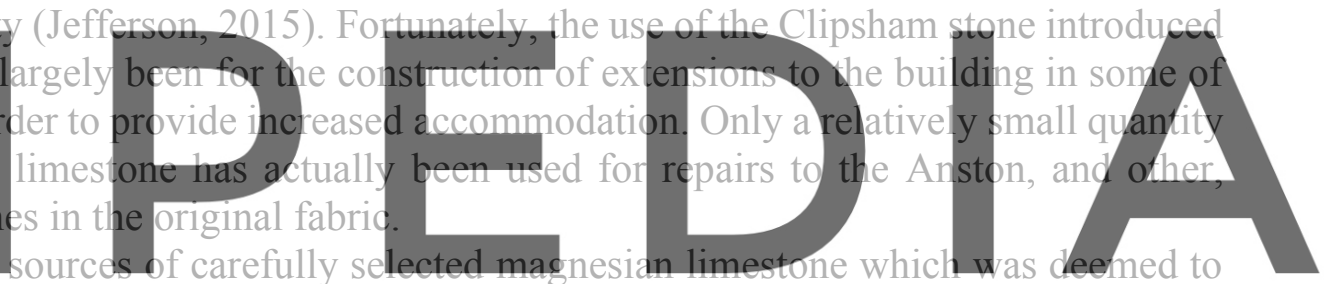

be compatible with the original stone from South Yorkshire. In the large-scale frost testing

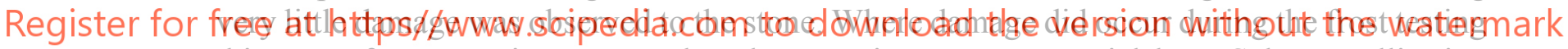

this was of a cosmetic nature rather than causing severe material loss. Salt crystallisation testing also showed low levels of losses in standard and non-standard regimes. The Cadeby stone is likely to decay eventually by surface blistering due to magnesium sulphate crystallisation, but this is not anticipated for an extended interval. In conclusion both Anston (Harrycroft) and the Cadeby magnesian limestone materials tested were found to be durable. Both quarries contain variable stone, Cadeby has produced six different types of building stone. If the stone tested is representative of the materials exploited from the quarries, then an extended life span in use is suggested. The work highlights the difficulties in evaluation of likely stone performance from a single test. By using a variety of methods, the differential performance observed can be balanced. The results show that the magnesian limestone can be expected to be durable, but that the natural variability of the stone is such that considerable care must be exercised to ensure that the correct quality of stone is used. Durability is not the only consideration when selecting a stone for conservation use; petrographic, permeability, strength and colour after a period of weather are all important factors.

\section{Acknowledgements}

The authors wish to acknowledge T Brindley for construction of the wall, the input of the Harmer 2004 technical team (particularly Carl James for supporting the frost work; Callum McPherson for the sulphate testing; Steve Williams for technical team leadership). Proof reading by M Laycock and B Nightingale. 


\section{ORCID}

Elizabeth A Laycock http://orcid.org/0000-0003-3758-6829

Steven Hetherington http://orcid.org/0000-0002-9851-8478

\section{References}

Benavente, D. García Del Cura, M.A. Bernabéu, A and Ordóñez, S. (2001). Quantification of salt weathering in porous stones using an experimental continuous partial immersion method. Engineering Geology, Vol.59(3), 313-325 DOI: 10.1016/S0013-7952(01)00020-5

Cardell C. Benavente and D.Rodríguez-Gordilloa, J. (2008). Weathering of limestone building material by mixed sulfate solutions. Characterization of stone microstructure, reaction products and decay forms. Materials Characterization 59 1371-1385 DOI: 10.1016/j.matchar.2007.12.003

Elsden, J. V. and Howe, J. A. (1923). The Stones of London., Colliery Guardian, London

EN 12370 (1999). Natural stone test methods - Determination of resistance to salt crystallization. BSI:London. Goudie, A. S. (1986). Laboratory simulation of 'the wick effect' in salt weathering of rock. Earth Surface Processes and Landforms Vol 11 275-285

Hunt, B (2015). The stone that has rescued the Houses of Parliament. Natural Stone Specialist, May 2015

Jefferson (2015). Letter Dr David Jefferson, Jefferson Consulting 10 July 2015. Stone Specialist

https://www.stonespecialist.com/news/letter-dr-david-jefferson-jefferson-consulting

Jefferson D. and Henry A. (2016). Identifying and Sourcing Stone for Historic Building Repair. Historic England Technical Advice Note. Historic England: Swindon

Laycock, EA Spence, K, Jefferson, David P, Hetherington, S, Martin, B and Woods, Christopher (2008) Testing the durability of limestone for Cathedral façade restoration. Environmental Geology.

https://doi.org/10.1007/s00254-008-1333-x

Laycock, E.A. (2002). Ten years of frost testing at Sheffield Hallam University. Construction and Building Materials. Volume 16, Issue 4, June 2002, Pages 195-205 https://doi.org/10.1016/S0950-0618(02)00006-5
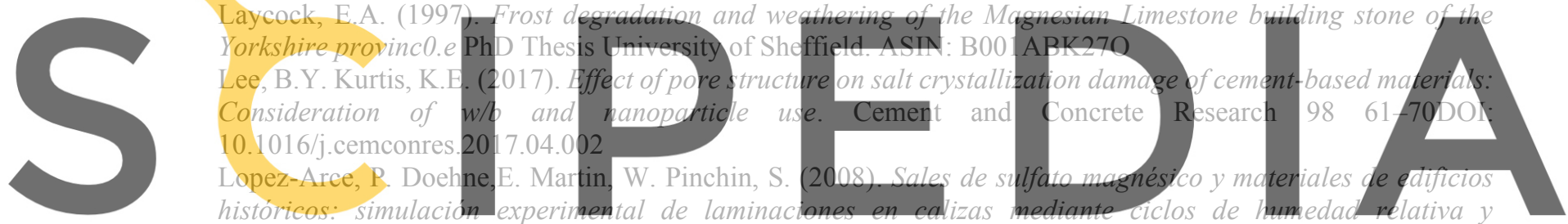

cristalización de sales. Materiales de Construcción Vol. 58, 289-290 125-142 ISSN: 0465-2746

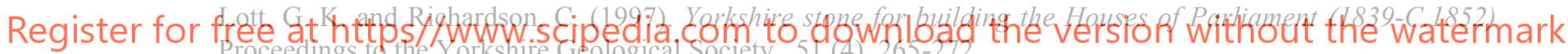

Palmer, T (2014). Understanding the Weathering Behaviour of Caen Stone. Journal of Architectural

Conservation. Volume 14, Issue 3. 43-54 https://doi.org/10.1080/13556207.2008.10785030

Richardson, C (1999). History Summary of the Chesterfield Canal. Kiveton Park and Wales History Society (http://www.kivetonwaleshistory.co.uk/heritage/chesterfield-canal/chesterfield-canal-history)

Shenton, C (n.d.). The Fire of 1834. The History of Parliament, British Political Social and Local History. Institute of Historical Research (C) Crown copyright and The History of Parliament Trust 1964-2019 https://www.historyofparliamentonline.org/periods/modern/fire-1834

Scherer, G.W.(2004). Stress from crystallization of salt. Cement and Concrete Research 34 1613-1624 DOI: 10.1016/j.cemconres.2003.12.034

Smith, D.B., (1995). Marine Permian of England. Geological Conservation Review Series, No. 8, Chapman and Hall: London, 205pp http://www.jncc.gov.uk/page-2953

Yates, T (2014). Identifying Caen Stone for Remedial Work. An Example from Cloister Court, Palace of Westminster. Journal of Architectural Conservation. Volume 14 Issue $3 \quad 55-58$ https://doi.org/10.1080/13556207.2008.10785031 